\section{É POSSÍVEL TRANSFORMAR EM PRODUÇÃO UNIVERSITÁRIA A EXPERIÊNCIA PSICANALÍTICA?}

\section{Pesquisando com o método}

psicanalítico. Fabio Herrmann e

Theodor Low enkron (orgs.). São Paulo: Casa do Psicólogo, 2004, 438 p.

\section{Iliana H orta W archavchik \\ Luciana Saddi \\ M agda Guimarães Khouri}

Psicanalistas da Sociedade Brasileira de Psicanálise de São Paulo (SBPSP)

O livro nasceu da II Jornada de Psicanálise e Pesquisa, da Associação Brasileira de Psicanálise (ABP), Jornada Pesquisando com o Método Psicanalítico, realizada na Sociedade Brasileira de Psicanálise de São Paulo (SBPSP), em maio de 2003. Foi organizado por Fabio Herrmann, membro efetivo da SBPSP e professor do programa de pós-graduação em psicanálise da PUC-SP, e Theodor Lowenkron, membro efetivo da SBPRJ, coordenador da Comissão de Pesquisa da ABP, professor da Faculdade de Medicina da UFRJ e do Programa de Pósgraduação em Psiquiatria, Psicanálise e Saúde Mental do Instituto de Psiquiatria da UFRJ-Ipub.

Pesqui sando com o método psicanalítico apresenta, principalmente, um retrato da produção de pesquisa psicanalítica feita na SBPSP. Está dividido em duas partes. Oferece, na primeira, ensaios que visam questionar o campo da pesquisa em psicanálise, contribuindo com subsídios para que o pesquisador compreenda e se posicione criticamente diante dessa prática, uma discussão relativamente nova em nosso meio. Seus autores, ligados à universidade, Theodor Lowenkron,
João Frayze-Pereira e Fabio Herrmann dedicam-se a problematizar as questões relativas à pesquisa em psicanálise que transita entre os fenômenos subjetivos e objetivos. Os ensai os interrogam a noção de método, noção que se caracteriza por levar o psicanalista a romper com um sentido preestabelecido e a recriar as idéias psicanalíticas.

Na segunda parte estão 28 trabalhos de pesquisa, sob a forma de artigos, com o objetivo de traçar um perfil da produção realizada por analistas da SBPSP. Aos autores foi pedido que selecionassem 0 processo de investigação, os procedimentos e os instrumentos utilizados no decorrer de suas pesquisas, bem como os impasses encontrados para que o método psicanalítico ganhasse destaque, sobressaindo-se aos resultados encontrados.

0 leitor está diante de uma obra que serve como referência àqueles analistas e demais profissionais de saúde mental que pretendem fazer um trabalho investigativo e se sentem, de certa forma, insatisfeitos com a pesquisa tradicional. E encontrará um grande leque de temas, questões e formas criativas de abordálas. 0 livro atende também às necessidades daqueles que gostariam de ampliar suas noções sobre o debate a respeito da natureza polêmica da pesquisa em psicanálise: ciência ou arte, clínica ou teoria? Quais as formas possíveis de transmissão e de publicação do nosso saber? Como legitimá-lo?Terá o analista de abandonar completamente sua prática quando quiser pesquisar, ou haverá uma zona de trânsito entre clínica e pesquisa?

Estas são importantes preocupações do analista na atualidade. Durante a maior parte do século $\mathrm{XX}$, a pesquisa e a prática analíticas foram termos raramente associados, a não ser na Universidade. Agora, porém, a pesquisa psicanalítica 
está na ordem do dia. 0 desafio fundamental é o seguinte: deve o analista abandonar seu procedimento clínico ao pesquisar o método criado por Freud, substituindo-o por estatísticas, grupos de controle, comentário teórico, ou será possível converter em investigação universitária o próprio processo interpretativo?

Sabemos que pesquisa é algo que os analistas estão sempre a fazer: bastaria saber como transformar nosso trabalho diário em pesquisa comunicável. Neste livro, são apresentados muitos trabal hos práticos, de diferentes ambições e inserções acadêmi cas, e de tamanhos e profundidades diferentes. E o objetivo do livro é mostrar como, valendo-se do método psicanalítico, os analistas conseguem perfazer o caminho que vai da clínica à pesquisa, do método às novas sugestões teóricas. Acreditamos que a psicanálise continuará a existir na medida em que puder ser reinventada dentro dela mesma.

Recebido em 2/3/2005

Aprovado em 4/ 4/ 2005

Iliana H ortaW archavchik

ilianaw @ dial data.com.br

Luciana Saddi

lucianasaddi@sbpsp.org.br

M agda Guimarães Khouri

magdakouri@uol.com.br

\section{DIMENSÕES DO AMOR}

A teoria do amor. Nadiá Paulo Ferreira. Rio de Janeiro: Jorge Zahar, 2004, 71 p. (Coleção Psicanálise Passo a Passo, v.38)
Julia Cristina Tosto Leite
Psicanalista; mestre em Pesquisa e Clínica em Psicanálise pelo IP/ U erj. Associada ao Corpo Freudiano do Rio de Janeiro - Escola de Psicanálise

A proposta de Nadiá Ferreira é apresentar as concepções do amor na obra de Freud e no ensino de Lacan. Psicanalista e pesquisadora dedicada ao tema, a autora realiza um abrangente mapeamento dos principais eixos e desdobramentos de uma discussão que se impõe desde a aurora da psicanálise: a construção do conceito de transferência, um dos pilares da definição do novo campo, é derivada do reconhecimento precoce, por Freud, da "estranha relação de amor", surgida na cena analítica e tomada como um elemento ao mesmo tempo perturbador e motor de cura. Em vez de recuar, Freud assume a posição firme de aprender com o inesperado fenômeno do amor. Seu percurso teórico articula-se, naturalmente, com os conceitos centrais da psicanálise, particularmente a sexualidade, e culmina na formulação da dualidade Eros e pulsão de morte, mudança cujas conseqüências éti cas Lacan irá destacar.

Como ponto de partida, a autora analisa o lugar ocupado pelo amor no discurso dos amantes e na poesia. Ao sublinhar a força do mito do amor, força esta sustentada pela promessa de felicidade plena nas chamadas "histórias de amor", aponta também a estratégia desse mito: manter essa promessa de felicidade, afastando o impossível, uma das denominações do real para Lacan, ou transformando-o em proibido. Freud já observara que 0 amor tende a 